\title{
Deepening ESP Reading Comprehension through Visualization
}

\author{
Seyyed Mahdi Erfani \\ Damghan University, Iran \\ Email: smerfani@yahoo.com \\ Abutaleb Iranmehr \\ Shahrood University of Technology, Iran \\ Email: airanmehr946@yahoo.com \\ Hossein Davari \\ Tarbiat Modares University (TMU), Tehran, Iran \\ Email: hdavari1358@yahoo.com
}

\begin{abstract}
Teaching through visualization or in Tomlinson's (1998) terms "the ability to build mental pictures or images while reading" is known as an efficient strategy in language learning. Thus, this research was done to investigate the role of this strategy on ESP reading comprehension ability of Iranian students whose syllabus mostly focuses on this skill. To do so, two homogeneous groups of thirty served as the experimental and the control groups. Before treatment, pretest was performed in both groups. The participants in the experimental group were taught through visualization and the ones in the control group were taught through the conventional method common in Iranian ESP setting by the same teacher. At the end of the treatment which took twenty-four sessions of two hours during twelve weeks, a test of 30-item multiple choice in ESP reading comprehension was administered to both groups. Finally, drawing on t-test at the 0.05 level of significance, the researchers compared the participants' performances to study such an effect. The findings revealed the significant advantage of using visualization in promoting ESP reading comprehension ability of university students.
\end{abstract}

Index Terms - visualization, ESP, reading comprehension

\section{INTRODUCTION}

The essential position of reading comprehension in EFL settings has turned this skill to the most important one needed for the learners' success, in a way, it is often known as the main goal of English language learning in such contexts. Undoubtedly, ESP as a trend in the framework of ELT (Dudley-Evans \& St John, 1998) is not an exception to the rule and obviously the framework of ESP textbooks in such contexts reveals that the most important skill is reading.

Glancing at the current ESP textbooks in Iranian academic setting also indicates that reading comprehension has been the main skill for learners' success (Erfani, et al., 2010; Farhady, 2005). But, In spite of the prominent presence of this skill in Iranian ESP trend, the available findings in this scope show that focusing on reading based on traditional approaches has been the source of many problems. In Shokouhi's words (2005) inadequate approaches, including Grammar Translation Method (GTM), have been the basic approaches and frameworks for ESP textbooks, thus significant approaches, strategies and techniques which have shown to be effective in enhancing learners' reading comprehension ability, have mostly been neglected in these books.

While in such traditional approaches, reading has been considered as a receptive skill, thanks to the new findings it is strongly believed that reading comprehension cannot be confined to a receptive skill and like other skills is a productive and interactive one. In Ghazanfari's terms (2009) reading is now considered as an interactive skill as a process of active and internal thinking in which meaning is constructed through interactions between the printed page and the reader. In other words, the important role of reader in meaning construction is so essential that Braunger and Lewis (1998) maintain that readers do not take in print and receive words off the page, but they actively engage with the text and build their own understanding. Thus, to meet this end, visualization (sometimes also referred to as visualizing, sensory imaging or imaging process) or the result of forming mental images while reading and recalling texts has been assumed to be one of the efficient strategies in reading comprehension. As Tomlinson (1998) asserts, visualization is functionally significant in L2 as well as L1 reading comprehension and recall.

\section{STATEMENT OF THE PROBLEM}

ESP courses favor a great deal of attention and emphasis among the EFL practitioners and learners especially at universities. Due to the problems with traditional approaches applied in ESP textbooks and classes from one side and 
the importance of reading comprehension in academic studying of English from the other side, it seems necessary to investigate whether visualization as a reading comprehension strategy has any effect on improving ESP reading comprehension ability of university students. Therefore, this study aims to investigate such an effect.

\section{THEORETICAL BACKGROUND}

McNamara (2007) defines visualization as a metacognitive reading strategy which results in comprehension gains. Pressley (2000) introduces visualization as the fifth strategy along with prediction, questioning, clarification and summarization. As an advocate of multicomponential approaches to comprehension instruction, he maintains that visualization which is based on generative learning could be used effectively in reading comprehension. Johnson-Laird (1983) believe that the ultimate act of reading is the creation of a mental model and in this regard, McNamara (2007:298) asserts "although not all mental models are visual, research on the importance of imagery and visualization during information processing and reading has a long and respected history."

Moreillon (2007) provides visualization as a strategy which relies on the effective use of senses in making meaning. Defining it as a strategy that goes beyond the text, McNamara (2007) introduces visualization or imagery as a useful way of going beyond the text, because visualizing induces the reader to draw on prior knowledge and thus ground ideas discussed in the text. In fact, visualization as the ability to build mental pictures or images while reading would greatly depend upon our prior knowledge and engagement with the topic (Keene and Zimmermann, 1997). Findings of Gambrell and Jawitz (1993) reveal that if we are able to construct any mental image from what we read, it is likely that our understanding of the material will be greater than had we not. According to Keene and Zimmermann (1997), using mental images while reading helps students immerse in rich details. In their words, reader's prior knowledge on the topic of the text can make learners become more engaged and make the text for them more impressive.

The available research on the topic of visualization proves that learners who create visual images before, during and after reading improve their comprehension (Douville, 1999; Fillmer \& Parkay, 1990; Sadoski \& Paivio, 2001). Wood (2002) maintains that while reading, good readers use sensory images. In this regard, Tomlinson (1998) believes that for many L1 readers, visualization plays a major role in helping them to achieve involvement, comprehension, retention and recall. Therefore, there is little doubt that visualization is functionally significant in L1 reading and there is a strong possibility that it could play a beneficial role in L2 reading, too. In his words (1997), this ability can increase the comprehension of a text. He asserts that it can enable the reader to make hypotheses which can be retained visually until they are confirmed or revised as new information becomes available from the text.

Moreillon (2007) also maintains that students who can make connections between their sensory experiences and language can then use their senses to comprehend a text. According to Willis (2008), visualization could facilitate connections to their stored patterned prior knowledge. Findings of Harris and Sipay (1990) also reveal that visualization connect new vocabulary to previous knowledge. In this regard, Rosenblatt (1978) believes that this strategy encourages students to make a personal connection to the text.

In McNamara's (2007) words, research in the area of visualization has been promising: "participants who are asked to visualize text contents remembered and comprehended more than control students." In his words, the available literature on the topic reveals that numerous studies report important comprehension gains by experimental groups that were either encouraged or taught to visualize while reading. As noted in some studies like Bell (1991), Center, et al (1999), Gambrell and Jawitz (1993), Mayer \& Sims (1994) and Oakhill \& Patel (1991), the effect of visualization have been investigated and their findings revealed that it can be used as an efficient strategy for meaningful learning, but its effects on ESP reading comprehension has not been studied so far.

Now, conceiving the efficacy of this strategy as well as observing the paramount presence of reading comprehension as the main skill in Iranian ESP textbooks as well as the inefficiency of the traditional methods and strategies used in such classes, the researchers attempted to integrate visualization as a key efficient reading strategy in ESP classes.

Since it is known that visualization is often easiest to explain and toughest to really use effectively, there are a variety of activities to make the learners familiar with. For example, reading the text aloud and at each stopping point, have students sketch what they are picturing in their minds is known as one of the basic procedures applicable for different settings or as Moreillon (2007) writes, inviting students to close their eyes and imagine the text as it is read aloud, and then asking them to share the pictures in their heads, is the best technique used to teach visualization.

\section{METHODOLOGY}

In line with the attempt to determine whether visualization has any effect on improving ESP reading comprehension ability, the following null hypothesis was formulated: Visualization does not have any effect on the improvement of ESP reading comprehension ability of Iranian students majoring chemistry.

\section{A. Participants}

This study involved 60 students, of males and females, majoring chemistry at Damghan University. They were enrolled in ESP course. They were randomly chosen to serve as the experimental and control groups.

\section{B. Design}


The research method followed was a quasi-experimental and research design was pre and post test with control group. Two homogeneous groups of intermediate students served as the control \& experimental groups. Visualization as a treatment was offered to the experimental group. Two tests as pretest \& posttest were administered in each group.

\section{Procedure}

After randomly assigning the participants to two equal groups, the experimental group was encouraged to visualize before, whilst and after reading the ESP texts in the class. They were taught through visualization for twelve weeks and during this time, participants of control group were taught through the conventional method. After instruction, a posttest was performed for both groups. In a more precise word, this group was not asked or encouraged to apply this strategy in the process of reading the ESP passages.

\section{RESUltS AND DATA ANALYSIS}

To accept or reject the null hypothesis, the data obtained through pretest and posttest was analyzed through t-test. As mentioned the design of the study was pretest-posttest control group design, thus the researchers administered a pretest to both groups. The results can be presented as follows:

TABLE 1:

THE T-TEST FOR THE PRETEST SCORES

\begin{tabular}{|l|l|l|l|l|}
\hline Group & $\mathrm{N}$ & $\mathrm{M}$ & $\mathrm{SD}$ & t-observed $=1.12$ \\
\hline $\mathrm{Ge}$ & 30 & 18.26 & 2.09 & \\
\hline $\mathrm{Gc}$ & 30 & 18.20 & 2.17 & \\
\hline $\mathrm{P}<0.05$ & d.f. $=58$ & t-critical $=2.00$ \\
\hline
\end{tabular}

At the end of the study, the posttest was given to the groups and to conform or reject the hypothesis, a t-test was used. The results of the posttest are as following:

TABLE 2:

THE T-TEST FOR THE POSTTEST SCORES

\begin{tabular}{|l|l|l|l|l|}
\hline Group & $\mathrm{N}$ & $\mathrm{X}$ & $\mathrm{SD}$ & t-observed= 5.00 \\
\hline $\mathrm{Ge}$ & 30 & 24.76 & 1.96 & \\
\hline $\mathrm{Gc}$ & 30 & 21.93 & 2.40 & \\
\hline $\mathrm{P}<0.05$ & d.f. $=58$ & t-critical $=2.00$ \\
\hline
\end{tabular}

Considering $(\mathrm{t}$-observed $=1.12<\mathrm{t}$-critical $=2)$ at the pretest and $(\mathrm{t}$-observed $=5.00>\mathrm{t}$-critical $=2.00)$ at the posttest shows that a remarkable difference between the two groups at the posttest stage is obvious. After comparing the two mean scores through t-test calculations, the researchers felt justified that the null hypothesis could be rejected. While the two groups were not significantly different at the outset of the study, they scored differently on the posttest and the difference was statistically significant. Thus, the researchers are satisfied to claim that the final calculated t-test (5.00) at 0.05 level of probability is due to the independent variable i.e. visualization.

\section{CONCLUSION AND PEDAGOGICAL IMPLICATIONS}

The current findings seem to complement and lend support to the related available findings. The present study has focused on the extent to which visualization can enhance ESP reading comprehension of university students. Finding revealed that it could be cogently argued that this strategy do aid ESP reading comprehension of Iranian students. To put it simply, the visualizers outperformed the non-visualizers on the ESP reading comprehension posttest.

In sum, based on the results of this research, the following pedagogical implications might be presented:

First, visualization as a key effective reading comprehension strategy can be a useful alternative for university ESP classrooms.

Second, The instructor's observations revealed that the procedures used in the experimental group triggered off the students to participate more actively in discussions and devoted more attention and interest to the topic.

Third, strategies like visualization might remove the strictness and formality of language learning classrooms and allow students, as one important side of ESP instructional transition, to engage more actively.

The last but not least, the instructors' creativity to use efficient strategies like visualization might cover some obvious shortcomings of textbooks.

\section{REFERENCES}

[1] Bell, N. (1991). Gestalt Memory: A Critical factor in language comprehension. Annals of Dyslexia, 41, 246-260.

[2] Braunger, J. \& Lewis, J. (1998). Building a knowledge base in reading, 2nd edition. Newark, NJ: International reading Association.

[3] Center, Y., Freeman, L., Robertson, G., \& Outhred, L. (1999). The effect of visual imagery training on the reading and listening comprehension of lower listening comprehenders in year 2. Journal of Research in Reading, 22, 241-256. 
[4] Douville, P. (1999). "It's like a video camera in my head": reading and multi-sensory imaging within a constructivist framework. Presentation for the national Reading Conference, Orlando, Florida.

[5] Dudley-Evans, T \& St John, M. J. (1998). Developments in English for Specific Purposes: A multi-disciplinary approach. Cambridge University Press.

[6] Erfani, S. M., Iranmehr, A. \& Davari, H. (2010). Using task-based instruction as an alternative approach in ESP materials development in Iranian academic context. Proceedings of the First Conference on New Perspectives in ELT, Linguistics and Literature, Sanandaj: Iran.

[7] Farhady, (2005). Farhady, H. (2005). Reflections on and directions for ESP materials development in SAMT, in Kiani \& Khayamdar (eds.) Proceedings of the First National ESP/EAP Conference, vol.3, Tehran, SAMT Publication.

[8] Fillmer, H. T. \& Parkay, F.W. (1990). Imagery: A neglected correlate of reading instruction. Paper presented at the Annual Meeting of the International Reading Association, Atlanta, Georgia.

[9] Gambrell, L. B. \& Jawitz, P. B. (1993). Mental Imagery, text illustrations, and children's story comprehension and recall. Reading Research Quarterly, 28 (3), 265-273.

[10] Harris, A. \& Sipay, E. (1990). How to increase reading ability: A guide to developmental and remedial methods. New York: Longman.

[11] Ghazanfari, M. (2009). The Role of Visualization in EFL Learners' Reading Comprehension and Recall of Short Stories. Iranian Journal of Applied Language Studies Vol.1 - No.1.

[12] Johnson-Laird, P. (1983). Mental Models. Cambridge, Mass.: Harvard University Press.

[13] Keene, E. O. \& Zimmermann, S. (1997). Mosaic of thought: Teaching reading comprehension in a reader's workshop. Portsmouth, NH: Heinemann.

[14] Mayer, R. E. \& Sims, V. K. (1994). For Whom is a Picture worth a thousand words? Extension of a Dual-Coding Theory of Multimedia Learning. Journal of Educational Psychology, 86 (3), 389-401.

[15] McNamara, D. S. (2007). Reading Comprehension strategies: Theories, Interventions, and Technologies. Mahwah, NJ: Lawrence Erlbaum Associates, Inc.

[16] Moreillon, (2007). Collaborative Strategies for Teaching Reading Comprehension: Maximize Your Impact. American library Association, Chicago.

[17] Oakhill J. V. \& Patel, S. (1991). Can imagery training help children who have comprehension problems? Journal of Research in reading, $14,106-115$.

[18] Pressley, M. (2000). What should comprehension instruction be the instruction of? In M. L. Kamil, P. B. Mosenthal, P. D. Pearson, \& R. Barr (Eds.), Handbook of reading research: Volume III (pp. 545-561). Mahwah, NJ: Lawrence Earlbaum Associates, Inc.

[19] Riazi, A. (2005). Features of quality EAP textbooks: insights from literature and book reviews, Kiani, G. R \& Khayamdar, M. (Eds.) Proceedings of the First National ESP/EAP Conference, vol.1, Tehran, SAMT Publication.

[20] Rosenblatt, L. M. (1978). The reader, the text, the poem: The transactional theory of the literacy work. Carbondale, IL: Southern Illinois University Press.

[21] Shokouhi, H. (2005). A New Discourse Plan for the Iranian University ESP Textbooks. In Kiani G. R \& Khayamdar, M. (Eds.) Proceedings of the First National ESP/EAP Conference, vol.3, Tehran, SAMT Publication.

[22] Sadoski, M. \& Paivio, A. (2001). Imagery and text: A dual coding theory of reading and writing. Mahwah, NJ: Laurence Erlbaum Associates, Inc.

[23] Tomlinson, B. (1997). The role of visualization in the reading of literature by learners of a foreign language (unpublished $\mathrm{PhD}$ thesis, University of Nottingham). Microfilmed version: The British library, British Thesis Service.

[24] Tomlinson, B. (1998). Seeing what they mean: helping L2 readers to visualize, in B. Tomlinson (ed.), Materials development in language teaching, Cambridge University Press, pp. 265-78.

[25] Willis, J. (2008). Teaching the brain to read: strategies for improving fluency, vocabulary and comprehension. Association for Supervision and Curriculum development. Alexandria, Virginia, USA.

[26] Wood, K. D. (2002). Aiding comprehension with the imagine, elaborate, predict, and confirm (IEPC) strategy. Middle School Journal, retrieved March 16, 2009 from http://www.nmsa.org/research/res_articles_ian202b.htm.

Seyyed Mahdi Erfani received his MA in linguistics in 1993 from Ferdousi University, Mashad, Iran. He is currently a lecturer of Damghan University, Iran. His interests include ESP, machine translation, materials development \& sociolinguistics and has published and presented papers in these areas. He has co-authored two books for university students which are currently taught nationwide.

Abutaleb Iranmehr received his MA in TEFL in 1998 from Teacher Training University, Tehran, Iran. He is currently a lecturer of Shahrood University of Technology, Iran. His interests include ESP, materials development, teaching methodology and psycholinguistics and has published and presented papers in these areas. He has co-authored two books for university students which are currently taught nationwide.

Hossein Davari received his MA in linguistics from Tarbiat Modares University (TMU), Tehran, Iran, and his MA in TEFL from Payame Nour University (PNU) and currently is a PhD candidate in linguistics at TMU. He is a lecturer of PNU, Damghan, Iran. His interests include materials development, sociolinguistics, lexicography \& ESP and has published and presented papers in these areas. He has co-authored two books for university students which are currently taught nationwide. 